\title{
Fiduciary Dispute Settlement of Murabaha Contract in PT. Al-Ijarah Indonesia Finance
}

\author{
Riska Wijayanti ${ }^{1}$ and Kartika Marella Vanni ${ }^{2}$ \\ ${ }^{1}$ Faculty of Islamic Economics and Business, UIN Walisongo \\ Semarang \\ email: riskawijayanti@walisongo.ac.id \\ ${ }^{2}$ Faculty of Islamic Economics and Business, UIN Walisongo \\ Semarang \\ email: kartikamarellavanni@walisongo.ac.id
}

\begin{abstract}
This study examines the authority of dispute settlement body of a bad financing in murabaha contracts with a collateral of Daihatsu car year 2011. According to DSN Fatwa Number 04/DSN-MUI/ IV/2000 concerning Murabaha the placement of fiduciary on murabaha contract objects is indeed permissible, but it becomes ambiguous when murabaha objects which are used as collateral in the financing process that have not been repaid are lost, causing late installment payments. The customer argued that the late payment was due to the embezzlement of murabaha objects by third parties beyond the expectations or control of the customer. This study also examines the legal liability for late settlement of murabaha sale and purchase by customers due to the loss of murabaha objects which at the same time become collateral in murabaha financing contracts. This research is normative legal research with a legal approach and a case approach. This study concludes that Religious Courts have the authority to decide disputes that occur between customers (mushtari) and sharia financial institutions (sahib al-māl) for late repayment of murabaha financing. Based on the principle of accountability based on the element of error, the customer (mushtari) has legal responsibility for his actions. Errors made by customers (mushtari) are in the form of negligence.
\end{abstract}

Keywords: Dispute settlement, bad financing, collateral security, murabaha contract, Islamic finance 


\section{INTRODUCTION}

Sharia financial institution has a function as financial intermediary that conducts collection and distribution of funds in accordance with prevailing regulations in meeting the needs of the community in economic sector. Planty needs of the community in the economic sector must be balanced with the existence of a fair legal certainty in order to create the effectiveness and efficiency of security in a financial transaction that is vulnerable to legal problems because there are things that deviate from the prevailing regulations. In this case, it is clearly seen that there is a close relationship between law and economics. Thus, legal system must exist as an embodiment of the economic system. It also can be seen in the opposite direction that nation's economic system will be reflected in its legal system (Rahardjo, 2009).

PT Al Ijarah Indonesia Finance is a sharia-based financial institution in which all transactions made apply sharia principles. One of those transactions is the murabaha contract. In murabaha financing contract, it is necessary to have an offer and acceptance to carry out buying and selling transactions. The seller clearly states the item being traded, including the purchase price and the profit to be taken while the buyer agrees by paying the price and profit requested.

In accordance with the development of the era the practice of sale and purchase is carried out through intermediaries such as Islamic financial institutions. Buyers who need the goods or objects come directly to Islamic financial institutions and express their desire to buy the goods. Islamic financial institutions as intermediaries will buy goods by conveying details of the price to the buyer at the initial stage. Afterward, the buyer pays it to Islamic financial institutions. In other words, Islamic financial institution here act as the party that finances the needs of the buyer in advance.

This basic scheme applies to murabaha financing transactions between PT Al Ijarah Indonesia Finance and its customers Agus Pujianto S.E. Bin Lie Gwan Lay, a customer who purchases one unit of midnight black Daihatsu/VVTI 13 XI DLX in 2011 through PT Al Ijarah Indonesia Finance. The agreed contract consists of 
total payments paid in the amount of Rp. 198,060,000. Since the payment is agreed to be settled in installments, the buyer has the obligation to make payments of Rp. 3,301,000 every month throughout 52 months. In this case, the financing is made through murabahah transaction. For the sake of preventive protection, both parties agree to make an agreement for pledging collateral under the contract of Fiduciary certificate No. W22.2536 AH.05.01 dated April 16, 2012 for 1 Daihatzu / VVTI 13 XI DLX Year 2011 which is the murabaha object itself. The status of the buyer here is the collateral provider while PT Al Ijarah Fianance is the recipient the guarantee. Here, both parties are subject against Law Number 42/1999 on Collateral Guarantee.

In implementing the murabaha contract, the first installment up to the seventh month runs smoothly where the buyer paid Rp. 3,301,000 monthly. However, the installment at 8th month did not go well. The buyer argued that the car which is the object of financing agreement was borrowed and then taken away by a third party which then caused the buyer to experience late payment. Due to this late payment installment, PT. Al Ijarah Finance finally reported it as criminal case to Yogyakarta Police Resort for the violation of Law Number 42/1999 concerning the Collateral Guarantee.

This criminal reporting of murabaha contracts carried out between PT Al Ijarah Finance and its customers is considered to violate sharia principles. This is because the dispute that occurs will not get Islamic solution if it goes into the police report since it has the possibility of being resolved through the District Court. Based on this notion, the customer registered the lawsuit under Religious Court on February 7, 2014. The judges of Yogyakarta Religious Court began to conduct a case review between PT. Al Ijarah Indonesia Finance (Defendant) with a customer named Agus Pujianto Bin Lie Gwan Lay (Plaintiff). It eventually had a legal force after being decided by a panel of judges at the Supreme Court on 31 August 2016 by refusing the Plaintiff's appeal and punishing the plaintiff to pay fees of the cases.

In his lawsuit the customer argued that PT Al Ijarah Finance had committed an illegal act by turning the murabahah financing 
agreement into a fiduciary guarantee agreement that violated the principles of sharia. PT. Al Ijarah Indonesia Finance has first reported the customer to Yogyakarta Police Resort by ruling out dispute resolution based on article 55 paragraph (1) and (3) of Law Number 21 Year 2008 where every sharia-related economic case should be settled first using sharia principles whether through deliberations, banking mediation, the National Sharia Arbitration Board (Basyarnas) or Religious Courts if it does not work through a non-litigation route.

The contract has a binding legal force for both parties as stipulated in the regulations. It is similar to regulations which states that if a debtor does not do what he promised, then the debtor is said to be default (Subekti, 1987). The legal impact that arises in resolving fiduciary collateral disputes must have legal certainty for the parties. This is necessary so that there is no confusion in resolving disputes which results slow legal process and an increasing disadvantage to the disputing parties in the future.

The implementation of murabaha financing transactions needs to be closely monitored to minimize aspects that are considered vulnerable to violations of Islamic sharia principles as stated in the Alquran, Hadith, prevailing laws and regulations as well as DSN MUI Fatwa or compilation of sharia economic law. This is because the regulations and experience in the field of Islamic financial institutions which are still relatively new can lead to many loopholes in violation of the law which ultimately lead to losses for both parties who has no prior knowledge and experience in this matter. Based on the above explanation, the authors are interested in making further research on "Fiduciary Disputes Settlement of Murabaha Contract at PT. Al Ijarah Finance Islamic Financial Institution Against Supreme Court Decision No. 452k / Ag / 2016"

The problems in this study are as follows. First, how does the implementaion of regulations in an authorized dispute resolution institutions settle fiduciary collateral disputes in sharia financial institutions? Secondly, how is buyers' legal responsibility for the wrongdoings of third parties which caused delays in the payment 
of murabaha financing installments in Islamic finance institutions of PT Al Ijarah Indonesia Fianance.

Based on the formulation of the problem above, the purpose of this study is to find out the implementing regulations and the authority of the dispute resolution agency when a guarantee collateral dispute occurs in the murabaha financing agreement at the Islamic financial institution PT Al Ijarah Indonesia Finance. Second, to analyze the legal liability of the city due to the presence of third parties which caused delays in installment payments on murabaha financing contracts in the PT Al Ijarah Fianance Islamic financial institutions.

\section{LITERATURE REVIEW}

\section{Theory on the Murabaha Contract Agreement}

In the Qur'an there are at least 2 (two) terms related to the agreement (Badrulzaman, 2001) which are the word al-'aqdu and the word al-'ahdu. Qur'an uses the first word in the sense of engagement or agreement, while the second word in the Qur'an means time, message, improvement and promise or agreement (Anshori, 2010). This research is more relevant to the word al'aqdu where in the Qur'an means engagement or agreement.

Epistemologically, contract means binding or connecting, while terminologically contract is an agreement in an agreement between two or more parties to do or not do certain legal actions as stipulated on Supreme Court Regulation Number 02/2008 on Compilation of Sharia Economic Law. Islamic jurists, divided the contract into two types, named contract and unnamed contract. The sale and purchase agreement of an item between parties in Islam is in the category of a contract called the murabaha contract. In the contract, it is necessary to have offer and acceptance to carry out sale and purchase transactions (Mardani, 2013). In murabaha, the seller must clearly states the offer of the item being traded, including the purchase price and the profit to be taken while the buyer clearly accepts it by paying the price and profit.

The definition of financing is mentioned in the provisions of Article 1 number 3 of Bank Indonesia Regulation Number 9 / 19 / 
PBI / 2007 which states: Financing is the provision funds or bills/ receivables that can be in the form of:

a. Investment transactions that are based, among other things, on mudharabah and / or musyarakah contracts.

b. Lease transactions based on, inter alia, the ijarah contract or the ijarah agreement with the option to transfer ownership (ijārah muntahiyah bittamlīk).

c. Sale and purchase transactions that are based on various types of murabaha, salam, and istishna contract.

d. Loan transactions based on, among others, the qardh contract

e. Multi-purpose transactions based on, among others, ijarah or kafalah contracts.

Based on these provisions it can be seen that financing is the provision of funds or bills / receivables which can be in the form of investment transactions, leases, buying and selling, loans, and multi-service.

In Article 20 paragraph (6) of the Supreme Court Regulation Number 02/2008 on Compilation of Sharia Economic Law states that the meaning of murabaha financing is:

"Mutual benefit financing is carried out by Shahib al-Mall with those in need through buying and selling transactions with an explanation that the price of procurement of goods and selling prices have more value which is profit or profit for Shahib al-mal and purchases are made in cash or installments".

From the definition above we can understand that the procurement of goods and the selling price of murabaha objects in murabaha financing must be known by sharia financial institutions and the buyer. Islamic financial institutions in this case must get profits from the sale of murabaha objects so that the business can continue to run. The murabaha payment system can be done in cash or instalment. The type of murabaha which is mostly used by Islamic financial institutions is murabaha based on orders where the payment method can be cash or several times of instalment. 


\section{Credit Risk in Murabaha Contract}

The risk has binding consequences for both parties as stipulated in the regulations. The regulation itself states that if the debtor does not do what he promised, then he is said to have defaulted (Subekti, 1987). However, it is not the default matter that always might raise from the contract. Sometimes a contract raises other legal issues that may not yet be regulated in the law and still require another legal research.

The existence of risk causes consequences as to who should be responsible for the murabahah financing contract when a loss occurs to one of the parties. However, the possibilities for the risks that exist in the murabahah financing agreement can be anticipated by looking at the usual risks, including (Mardani, 2015):

a. Default or negligence where the customer deliberately does not pay installments.

b. Comparative price fluctuations. This happens if the selling price of goods on the market rises after the bank buys it for the customer. The bank cannot change the selling price.

c. Customer refusal. Goods sent can be rejected by the customer for various reasons. It could be because it was damaged in transit, so the customer does not want to accept it. That is why it is better to cover the murabaha object using insurance. Another possibility is because the customer feels that the specifications of the item are different from what he ordered. If the Islamic financial institution has signed a purchase and sale contract, the item will become the property of the bank. Thus, banks have the risk to sell it to other parties.

d. On sale. Murabaha is trading with debt, so when the contract is signed, the goods belong to the customer. The customer is free to do anything about his assets, including to sell them. If this happens, the risk for default will be large.

\section{Guarantee on the Practice of Islamic Financial Institutions}

In Law Number 21/2008 on Sharia Banking, the term collateral is used to interpret a guarantee which read, "Collateral is an additional guarantee, either in the form of movable or 
immovable property, which is given by the owner of collateral to a Sharia Bank and / or Islamic financial institutions to guarantee settlement of obligations of the Facility Recipient Customer."

According to positive law, a guarantee is something given to a creditor submitted by the debtor to create confidence and guarantee that the debtor will fulfill obligations that can be valued with money arising from the engagement (Hadisoeparpto, 1984).

Guarantees in positive law are divided into two types, namely (Salim, 2004):

a. Personal guarantees. Individual guarantees do not give precedence over certain objects, but are only guaranteed by someone's assets through people who guarantee the fulfillment of the relevant agreement.

b. Guarantees in the form of asset. Asset guarantees give precedence over certain objects and have inherent nature and follow the object in question.

The types of material guarantees that are still valid are (Salim, 2004):
a. Pawn
b. Fiduciary guarantee
c. Mortgage right
d. Ship mortgage

According to Article 1 number 1 Law No. 42/1999 concerning Fiduciary Guarantees, Fiduciary is the transfer of ownership rights of an object on the basis of trust with the provision of objects whose ownership rights are transferred remain in the control of the owner of the object. Based on Article 1 number 2 of Law No. 42/1999 concerning Fiduciary Collateral, it can be understood the fiduciary object might include:

a. Movable objects consisting of tangible and intangible objects

b. Immovable objects, especially buildings that cannot be mortgaged as mentioned in Law No. 4/1996 concerning Mortgage Rights. 
In order to fulfill legal certainty for recipients of the collaterals and to fulfill the principle of publicity, the Fiduciary Law requires mandatory registration of guarantees at the Fiduciary Registration office. After registration, the fiduciary registration office will issue a fiduciary guarantee certificate that lists the "For Justice Based on the Supreme Godhead". Thus the fiduciary guarantee certificate has an executorial power which in consequence the fiduciary recipient can directly execute goods that are objects of fiduciary guarantee in case. if the fiduciary provider defaults (Lestari and Heriyani, 2009).

In the implementation of this execution, the leasing company must equip itself with a fiduciary guarantee certificate after taking a summons attempt against the debtor first. In the implementation process, the leasing party can appoint or cooperate with a third party (debt collector or collection service personnel) to carry out the execution (withdrawal of goods) politely and ethically.

\section{Dispute Resolution of Islamic Finance}

The legal relationship between customers and Islamic financial institutions will run well and smoothly if the parties obey what they have agreed in the contract they made. However, if one party fails or makes a mistake in fulfilling its obligations, the implementation of the contract will face obstacless, problems or even default on payment (Musjtari, 2012). A default in a financing agreement is a forerunner to disputes. Most disputes in the financing agreement are caused by non-performing financing (NPF).

When disputes dissent whether in its interpretation and implementation of the contents of the agreement, both parties will try to resolve them through fair discussion. Nevertheless, there is still a possibility that the dispute cannot be resolved through discussion. Such possibilities are increasingly large, especially in the increasingly diverse world of Islamic economic life (Ghofur, 2010). Settlement of receivables debt in sharia banking practices is carried out among others by (Musjtari, 2012): 
a. Resolved through internal institutions. In practice, it is done by the account officer, remidial, or by forming a task force of dispute resolution team;

b. Resolved through banking mediation;

c. Resolved through arbitration or through the National Sharia Arbitration Board (BASYARNAS)

d. Resolved through the Religious Courts.

Overall, dispute resolution can be divided into 2 major groups, namely non-litigation and litigation. Non-litigation is an alternative dispute resolution that is currently in high demand, especially for the business community because it is relatively simple, fast and the cost is cheaper. Whereas the litigation model means to proceed in front of a court hearing that has competence, both absolute and relative competence in certain disputes (Ghofur, 2010).

\section{RESEARCH METHODOLOGY}

This study is a legal research which carries out the normative legal research model. The legal material used in this study consists of primary legal material and secondary legal material. Collection of legal materials is carried out through document studies which are then analyzed qualitatively. The approach taken in this study is the legislative approach and case approach through the Supreme Court verdict No. 452K / AG / 2016. The results of this study will be presented in a qualitative descriptive form.

\section{RESULTS AND DISCUSSION}

Analysis of Supreme Court Decision No. 452K /Ag/2016 related to a fiduciary dispute at PT Al Ijarah Indonesia Finance

The legal relationship between buyer and PT. Al Ijarah Indonesia Finance is a contract based on sharia principles. The contract is a purchase of one unit Daihatzu / VVTI 13 car XI DLX in 2011 which will be then pledged as collateral. However, 
the payment began to run not smoothly because the car was taken away by another person (third party) who borrowed the object of the murabaha contract. Based on the default payment by the buyer, PT. Al Ijarah Indonesia Finance finally reported the case to Yogyakarta Polrestabes.

Disputes that cannot be resolved, either through mediatioin or arbitration will be settled through a judicial institution. The provisions of Law Number 48/2009 on Judicial Power explicitly states that in Indonesia there are 4 judicial institutions namely General Courts, Religious Courts, Military Courts and Administratial Courts. From the four judicial institutions each having different authority in deciding a dispute.

In Article 49 of Law Number 3 Year 2006 it is stated that the Religious Courts are one of the judicial institutions with a task and authority to examine, decide upon and settle cases at the first level among people who are Muslim in the fields of: marriage, inheritance, wills, grants, waqf, zakat, infaq, sadaqah and Islamic economics. Based on this regulation, a dispute arises from a murabaha contract which cannot be resolved through mediation or an arbitration becomes the authority of the religious justice institution.

This was also reinforced by the Constitutional Court Decision Number 93 / PUU-X / 2012 on Sharia Banking which stated that the Religious Court was the only court authorized to handle Islamic economic disputes. Indeed, previously it had caused contradictions because there were often several parties who tried to resolve Islamic economic disputes both through the District Court and the Religious Court which causes legal uncertainty for justice seekers. The return of authority of the religious court provides clear legal certainty because it does not only apply to Islamic banking financial institutions, but also to all Islamic financial institutions that use Islamic principles.

It is not a mistake when this dispute was submitted to the Religious Court. The only inaccurate thing is that when buyer as the party who should have been guilty of late payment reported back PT Al Ijarah Finance as the defendat. PT Al Ijarah Finance was alleged as committing illegal act by deflecting murabaha 
contract which its model follows Islamic principle as the basis for reporting the buyer to the Yogyakarta Police Resort.

After two years since the filing of this lawsuit to the Religious Court, the dispute was finally decided by the Supreme Court with a decision rejecting the appeal from the plaintiff Agus Pujianto S.E bin Lie Gwan Lay as the buyer. The Supreme Court's decision which upheld the decision of first level court was correct because from the dispute that occurred the Plaintiff clearly had bad intention. The buyer tried to take a legal loophole by distorting the facts and arguing a law breach by PT Al. Ijarah Finance so that the buyer will be free from default allegation caused by late payment of installments. In addition, the plaintiff also could not prove that the murabaha object was indeed taken away by a third party.

\section{Buyer's legal liability for the mistakes made by third party}

In case the buyer as a collateral provider is does not fulfil the payment agreement, then the execution of assets that become objects of fiduciary collateral can be done by several means which are:

a. Execution of the executorial title

b. The sale of assets which become the object of collateral over the power of the recipient of the collateral himself through public auctions as well as taking the repayment of his receivables from the proceeds of the sale (parate executie).

c. Underhand sales made based on an agreement between the buyer and the fiduciary recipient.

Particularly for parate executie in collateral objects which is regulated in Article 15 sub 3 of Law Number 42 of 199 on Collateral Guarantee is a conditional authority. The condition that must be fulfilled is the default debtor does not carry out the contract that has been made jointly. In our case, the buyer started not to pay the installment on the agreed time beginning in the eighth month because the car was taken away by people (third party). The late payment made by buyer is an act of default or breaking the promise of a contract because of its carelessness in 
safeguarding murabaha object which is also placed as collateral. Buyer's act is an mistake in the form of negligence that results in violations in criminal law.

In law there is a principle of accountability based on the element of mistake. The principle states that a person can be held legally liable if there is an element of mistake made. So that there are some legal consequences when PT Al Ijarah Indonesia Finance cannot claim its right to execute a unit of Daihatzu / VVTI 13 XI DLX 2011 for damages that are borne. First is the demands for compensation under Islamic civil law while the second is the buyer can be charged by criminal law to account for his mistake because the violation of regulation Article 15 sub 3 of Law No. 42 of 1999 on Collateral.

\section{CONCLUSION}

Collateral is a transfer of ownership rights from debtor to a creditor to guarantee that the debt will be repaid according to the agreement. In this case, based on Supreme Court's decision No. 452k / Ag / 2016 Agus Pujianto as buyer delays in paying installments. Delay in installment payments to PT. Al Ijarah Indonesia Finance led to reporting to Yogyakarta Police Resort. The act of reporting the buyer for the disappearance of the object of murabahah which has been pledged as collateral is a criminal act so that it can be resolved through criminal law. However, before the criminal settlement the parties must resolve the dispute through the civil law for compensation that needs to be paid through a religious court so that the case can be processed through criminal law. Musytari has legal responsibility for all his actions in the form of compensation for losses suffered by PT Al Ijarah Indonesia Finance and resolve all legal issues that occur as a result of negligence.

The research here concludes that it is not a mistake when this dispute was submitted to the Religious Court. It is only inappropriate when the buyer as the party that should be guilty of having delayed the installment payment reported PT Al Ijarah Indonesia Finance by distorting the fact that it was as if PT Al Ijarah Finance had committed an illegal act because it deflects 
the murabaha contract which is the principal agreement becomes collateral agreement as the basis for reporting the musytari to the Yogyakarta Police Resort. The Supreme Court's decision which upheld the verdict of first level court was correct because from the dispute that occurred, the Plaintiff clearly had bad intention by trying to take a legal loophole by distorting the facts and arguing against the law against PT Al. Ijarah Finance so that the buyer can be free default allegation. Therefore it is appropriate buyer must bear legal proceedings reported by PT Al Ijarah Finance. In addition, the Plaintiff also could not prove that the object of murabaha indeed had been taken away by a third party.

In this case, there are some legal consequences when PT Al Ijarah Indonesia Finance cannot claim its right to execute a unit of Daihatzu / VVTI 13 XI DLX 2011 for damages that are borne. First is the demands for compensation under Islamic civil law while the second is the buyer can be charged by criminal law to account for his mistake because the violation of regulation Article 15 sub 3 of Law No. 42 of 1999 on Collateral.

\section{BIBLIOGRAPHY}

Anshori, A. G. (2008). Penerapan Prinsip Syariah Dalam Lembaga Keuangan, Lembaga Pembiayaan, dan Perusahaan Pembiayaan.Yogyakarta: Pustaka Pelajar

Anshori, A.G. (2010). Hukum Perjanjian Islam di Indonesia. Yogyakarta: Gajah Mada University Press

Soenandar, T, Djamil, F., Badrulzaman M. D., Sjahdeini S. R., and Seopraptono H. (2001). Kompilasi Hukum Perikatan. Bandung: PT. Citra Aditya Bakti

Ghofur, A. (2010). Hukum Perjanjian Islam di Indonesia (Konsep, Regulasi dan Implementasi). Yogyakarta: Gajah Mada University Press

Hadisoeprapto, H. (1984). Pokok-pokok Hukum Perikatan dan Hukum Jaminan. Yogyakarta: Liberty

Sidik, H. S. (2004). Perkembangan Hukum Jaminan di Indonesia. Jakarta: PT. Raja Grafindo Persada 
Lestari, A. Y. and Heriyani E. (2009). Dasar-dasar Pembuatan Kontrak dan Akad. Yogyakarta: Mocomedia

Mardani. (2013). Hukum Perikatan Syariah di Indonesia. Jakarta: Sinar Grafika

Mardani. (2015). Hukum Sistem Ekonomi Islam. Jakarta: Rajawali Pers

Musjtari, D. N. (2012). Penyelesaian Sengketa dalam Praktik Perbankan Syariah. Yogyakarta: Parama Publishing

Rahardjo, S. (2009). Membangun dan MerombakHukum Indonesia (Sebuah Pendekatan Lintas Disiplin). Yogyakarta: Genta Publishing

Subekti. (1987). Hukum Perjanjian. Jakarta: PT Intermasa 